\title{
Urgences
}

\section{Un essai inédit...}

\section{Vianney Gallant}

Numéro 13, mars 1986

\section{Éclats d'atelier}

URI : https://id.erudit.org/iderudit/025213ar

DOI : https://doi.org/10.7202/025213ar

Aller au sommaire du numéro

\section{Éditeur(s)}

Urgences

\section{ISSN}

0226-9554 (imprimé)

1927-3924 (numérique)

Découvrir la revue

\section{Citer ce document}

Gallant, V. (1986). Un essai inédit... Urgences, (13), 35-35.

https://doi.org/10.7202/025213ar

Ce document est protégé par la loi sur le droit d'auteur. L'utilisation des services d'Érudit (y compris la reproduction) est assujettie à sa politique d'utilisation que vous pouvez consulter en ligne.

https://apropos.erudit.org/fr/usagers/politique-dutilisation/
Cet article est diffusé et préservé par Érudit.

Érudit est un consortium interuniversitaire sans but lucratif composé de l'Université de Montréal, l'Université Laval et l'Université du Québec à Montréal. Il a pour mission la promotion et la valorisation de la recherche. https://www.erudit.org/fr/ 


\section{Vianney Gallant}

Un essai inédit, l'écrit qui m'étrangle. Que de sueur pour une ligne, toujours piégée dans le tendre étain.

Souffrirai-je encore dans des draps glacés, mauves, jusqu'à ce qu'une grosse marge écrase le mythe? Hier je balisais des rides avec le voile du doute, contre le sacré, aux noces de l'encre. Folie grisée d'une chair.

Tu chercheras à t'étendre, fluide, lèvre bleuie, cernée déjà, fruit fustigeant à l'avance les mâles, I'homme. Tendre, faussé: le désir. Tu tireras désormais sur le verbe mais je bougerai sans cesse la cible. Sans écrin pour oublier le crime, la curée, tu viseras juste, possiblement au coeur. Je hurlerai ou je grandirai. II te restera, toi aussi, à t'abreuver sans t'affaiblir du mythe à la cigüe, comme au culte des noces. Fortes ou frêles je vous choisirais pourtant, malgré la tâche énorme, criée d'oasis nègres ou canot de femme sans duvet, fleur d'homme pourri à tripoter les rêves. Je ne t'aimerai plus muette, pour que tu m'enlèves. Lucide, tu crèveras la faible dague du désir pour amollir l'angle et la forme, et réunir avec l'objet la grâce sénile des ponts. J'errerai dans les pores, une docile petite magie encrée à l'Hydre signée sous une chair d'encre.

Un essai inédit, la quête m'étrange. Piège du tendre, fluide, aligné sur un corps. 